\title{
The Vulnerable clouded leopard Neofelis nebulosa in Nepal: an update
}

\author{
Y. GHimirey and R. AChARYA
}

\begin{abstract}
The Vulnerable clouded leopard Neofelis nebulosa is believed to be one of the most threatened felid species in Nepal. Information on its status and population size in the country mostly comprises crude estimates. We compiled information on the species' status and distribution from published papers, grey literature, camera-trap images, direct observations, pelt, zoo and museum records, wildlife seizures and verified newspaper reports. All confirmed records of the species (three museum specimens, one dead specimen, 13 live records (including from camera traps), and 14 pelts) were from eastern and mid-central Nepal. Two unconfirmed reports from the western and far-western regions of the country need to be verified. Although the status of the species is still uncertain, the frequency of confirmed and unconfirmed reports and the extent of the area of occurrence indicate that it is not as rare as previously assumed. The main threats to the species are habitat loss and illegal wildlife trade.
\end{abstract}

Keywords Camera trap, clouded leopard, habitat loss, Nepal, species distribution, wildlife trade

The clouded leopard Neofelis nebulosa, categorized as Vulnerable on the IUCN Red List, occurs from the Himalayan foothills in Nepal through mainland South-east Asia into China (Grassman et al., 2016). In Nepal the species is believed to occur along the mid-hills eastwards of Langtang National Park (Nowell \& Jackson, 1996). The species has been reported to occur in the protected areas of Annapurna Conservation Area, Chitwan National Park, Kanchenjunga Conservation Area, and Langtang, Makalu-Barun, Rara and Shivapuri Nagarjun National Parks (Jnawali et al., 2011; Pandey, 2012; Ghimirey et al., 2013; Lamichhane et al., 2014; D.W. Macdonald, pers. comm.). However, the claim that Rara National Park holds a clouded leopard population seems to be based on a single record of a misidentified leopard cat Prionailurus bengalensis pelt and can thus be discounted. The record of a clouded leopard in Annapurna Conservation Area at a straight-line distance of $170 \mathrm{~km}$ west of Langtang National Park in 2012 is the confirmed westernmost limit of the species' distribution (Nowell \& Jackson, 1996; Ghimirey et al., 2013). There have been reports of clouded

YADAV GHIMIREY (Corresponding author) and RAJU ACHARYA Friends of Nature, Nepal. E-mail yghimirey@hotmail.com

Received 1 April 2016. Revision requested 16 May 2016.

Accepted 20 May 2016. First published online 13 February 2017. leopards from Kailali district (Jnawali et al., 2011), Ghodaghodi Lake (Jnawali et al., 2011), Khaptad National Park (Khaptad National Park Management Plan, unpublished) and Api-Nampa Conservation Area (DNPWC, 2012). However, the reliability of reports west of Annapurna Conservation Area needs to be verified before drawing conclusions about the species' westward distribution.

The first study of the clouded leopard in Nepal was conducted in 2009 but the species was not recorded by camera trap for the first time until 2010, in Shivapuri Nagarjun National Park (Ghimirey et al., 2012; Pandey, 2012). The species was subsequently recorded by camera trap in Annapurna Conservation Area and Chitwan National Park in 2012 and 2013, respectively (Ghimirey et al., 2013; Lamichhane et al., 2014). A study conducted in 2015 detected the clouded leopard in Langtang National Park, as had been suggested previously (Nowell \& Jackson, 1996). Table 1 presents all records and unconfirmed reports of the clouded leopard in Nepal and Fig. 1 shows their location. Prior to these detections the species had not been detected in some previous studies, generating speculation that it might have gone extinct in the country. However, false absences may be attributed to the short duration of the studies and small study areas, as the clouded leopard is an elusive species. The species also has a small core area of use, which could further hinder detection, particularly if camera traps are deployed in places outside this core area and the duration of study is short. In Thailand the clouded leopard's core area of use has been calculated to be 2.9-6.0 \pm SD 2.1 $\mathrm{km}^{2}$, with home ranges of up to $51 \mathrm{~km}^{2}$ (Grassman et al., 2005; Austin et al., 2007). The species' core area of use could be similar in Nepal, considering the similar mountainous terrain. In Nepal only one study of the clouded leopard has covered an area of $>50 \mathrm{~km}^{2}$ (Pandey, 2012). It is imperative to conduct studies covering larger areas to reduce the probability of false absences.

The preferred habitat of clouded leopards has long been debated. Although the species is most strongly associated with primary tropical forest (Nowell \& Jackson, 1996; Brodie \& Giordano, 2012), clouded leopards have also been recorded in secondary forest, dry tropical forest, scrub and grassland, and mangrove swamps (Davies \& Payne, 1982; Dinerstein \& Mehta, 1989; Rabinowitz \& Walker, 1991). In Nepal, it has been suggested that the Mahabharat range is the best habitat for the species (C. McDougal, 1992, unpubl. data), which may be found at 1,000-2,500 m elevation (Upreti, 1999). However, clouded 
TABLE 1 All available confirmed records of the clouded leopard Neofelis nebulosa in Nepal (see numbered locations in Fig. 1), with year, location, geographical coordinates, altitude, type of evidence, and source of data. Blank cells indicate no data were available.

\begin{tabular}{|c|c|c|c|c|c|c|}
\hline ID & Year & Location & $\begin{array}{l}\text { Geographical } \\
\text { coordinates }\end{array}$ & Altitude (m) & Type of evidence & Source \\
\hline \multicolumn{7}{|c|}{ Museum specimens } \\
\hline & 1853 & Kathmandu & & & One pelt & Hodgson (1853) \\
\hline & 1858 & Nepal & & & One pelt in $\mathrm{BMNH}$ & Kitchener et al. (2006) \\
\hline & 1930 & Nepal & & & One pelt in $\mathrm{BMNH}$ & Kitchener et al. (2006) \\
\hline \multicolumn{7}{|c|}{ Live individuals } \\
\hline \multirow[t]{3}{*}{1} & 1977 & Langtang & $\begin{array}{l}28^{\circ} 11^{\prime} 21.58^{\prime \prime} \mathrm{N} \\
85^{\circ} 35^{\prime} 35.79^{\prime \prime} \mathrm{E}\end{array}$ & & $\begin{array}{l}\text { Direct observation of one } \\
\text { individual }\end{array}$ & Borradaile et al. (1977) \\
\hline & 1994 & $\begin{array}{l}\text { Tribhuvan } \\
\text { International Airport, } \\
\text { Kathmandu }\end{array}$ & & & $\begin{array}{l}\text { Three cubs seized alive from } \\
\text { trader }\end{array}$ & Shakya et al. (1999) \\
\hline & 1996 & Baghbazar & & & $\begin{array}{l}\text { Three cubs seized alive from } \\
\text { trader }\end{array}$ & Shakya (2004) \\
\hline 2 & 1987 & Janakpur & $\begin{array}{l}26^{\circ} 59^{\prime} 19.08^{\prime \prime} \mathrm{N} \\
86^{\circ} 3^{\prime} 5.98^{\prime \prime} \mathrm{E}\end{array}$ & & $\begin{array}{l}\text { Two cubs captured alive by } \\
\text { local people }\end{array}$ & Dinerstein \& Mehta (1989) \\
\hline 3 & 1988 & Nawalparasi & $\begin{array}{l}27^{\circ} 38^{\prime} 33.81^{\prime \prime} \mathrm{N} \\
83^{\circ} 44^{\prime} 43.88^{\prime \prime} \mathrm{E}\end{array}$ & & $\begin{array}{l}\text { One individual captured alive } \\
\text { by local people }\end{array}$ & Dinerstein \& Mehta (1989) \\
\hline 4 & 1988 & Pokhara & $\begin{array}{l}28^{\circ} 15^{\prime} 50^{\prime \prime} \mathrm{N}, 83^{\circ} \\
58^{\prime} 20^{\prime \prime} \mathrm{E}\end{array}$ & 900 & $\begin{array}{l}\text { Direct observation; stoned to } \\
\text { death }\end{array}$ & Dinerstein \& Mehta (1989) \\
\hline 5 & 2001 & Dillibazar, Kathmandu & $\begin{array}{l}27^{\circ} 42^{\prime} 25.4^{\prime \prime} \mathrm{N} \\
85^{\circ} 19^{\prime} 40.2^{\prime \prime} \mathrm{E}\end{array}$ & 1,315 & $\begin{array}{l}\text { One individual captured alive } \\
\text { by zoo officials }\end{array}$ & $\begin{array}{l}\text { Sarita Jnawali, Central Zoo, } \\
\text { Kathmandu (pers. comm.) }\end{array}$ \\
\hline 6 & 2002 & Jorpati, Kathmandu & $\begin{array}{l}27^{\circ} 43^{\prime} 39.9^{\prime \prime} \mathrm{N} \\
85^{\circ} 22^{\prime} 41.6^{\prime \prime} \mathrm{E}\end{array}$ & 1,344 & $\begin{array}{l}\text { One individual captured alive } \\
\text { by zoo officials }\end{array}$ & $\begin{array}{l}\text { Sarita Jnawali, Central Zoo, } \\
\text { Kathmandu (pers. comm.) }\end{array}$ \\
\hline 7 & 2007 & Dhamaura, Chitwan & $\begin{array}{l}27^{\circ} 36^{\prime} 44.8^{\prime \prime} \mathrm{N} \\
84^{\circ} 38^{\prime} 4.3^{\prime \prime} \mathrm{E}\end{array}$ & 229 & $\begin{array}{l}\text { One individual captured alive } \\
\text { by local people and brought } \\
\text { to National Park office }\end{array}$ & Ghimirey et al. (2014) \\
\hline 8 & 2010 & $\begin{array}{l}\text { Shivapuri Nagarjuna } \\
\text { National Park }\end{array}$ & $\begin{array}{l}27^{\circ} 48^{\prime} 53.1^{\prime \prime} \mathrm{N} \\
85^{\circ} 16^{\prime} 47.7^{\prime \prime} \mathrm{E}\end{array}$ & 1,985 & $\begin{array}{l}\text { Camera-trap image of one } \\
\text { individual }\end{array}$ & Pandey (2012) \\
\hline 9 & 2012 & $\begin{array}{l}\text { Annapurna } \\
\text { Conservation Area }\end{array}$ & $\begin{array}{l}28^{\circ} 22^{\prime} 52.2^{\prime \prime} \mathrm{N} \\
84^{\circ} 7^{\prime} 21.8^{\prime \prime} \mathrm{E}\end{array}$ & 2,274 & $\begin{array}{l}\text { Camera-trap image of one } \\
\text { individual }\end{array}$ & Ghimirey et al. (2013) \\
\hline 10 & 2013 & Chitwan & $\begin{array}{l}27^{\circ} 28^{\prime} 57.2^{\prime \prime} \mathrm{N} \\
84^{\circ} 12^{\prime} 46.4^{\prime \prime} \mathrm{E}\end{array}$ & 301 & $\begin{array}{l}\text { Camera-trap images of three } \\
\text { individuals }\end{array}$ & Lamichhane et al. (2014) \\
\hline 11 & 2014 & Langtang NP & & & $\begin{array}{l}\text { Camera-trap image of one } \\
\text { individual }\end{array}$ & $\begin{array}{l}\text { E. Can \& D. Macdonald (pers. } \\
\text { comm.) }\end{array}$ \\
\hline \multicolumn{7}{|c|}{ Pelt records } \\
\hline & 1988 & Kathmandu & & & Four pelts for sale & Barnes (1989) \\
\hline 12 & 1991 & $\begin{array}{l}\text { Sunumla, } \\
\text { Sankhuwasava }\end{array}$ & $\begin{array}{l}27^{\circ} 11^{\prime} 37.01^{\prime \prime} \mathrm{N} \\
87^{\circ} 23^{\prime} 41.03^{\prime \prime} \mathrm{E}\end{array}$ & 1,200 & One pelt from hunter & $\begin{array}{l}\text { Karan Bdr. Shah (pers. } \\
\text { comm.)* Natural History } \\
\text { Museum, Kathmandu }\end{array}$ \\
\hline & 1992 & Kathmandu & & & Two pelts for sale & Van Gruisen \& Sinclair (1992) \\
\hline
\end{tabular}




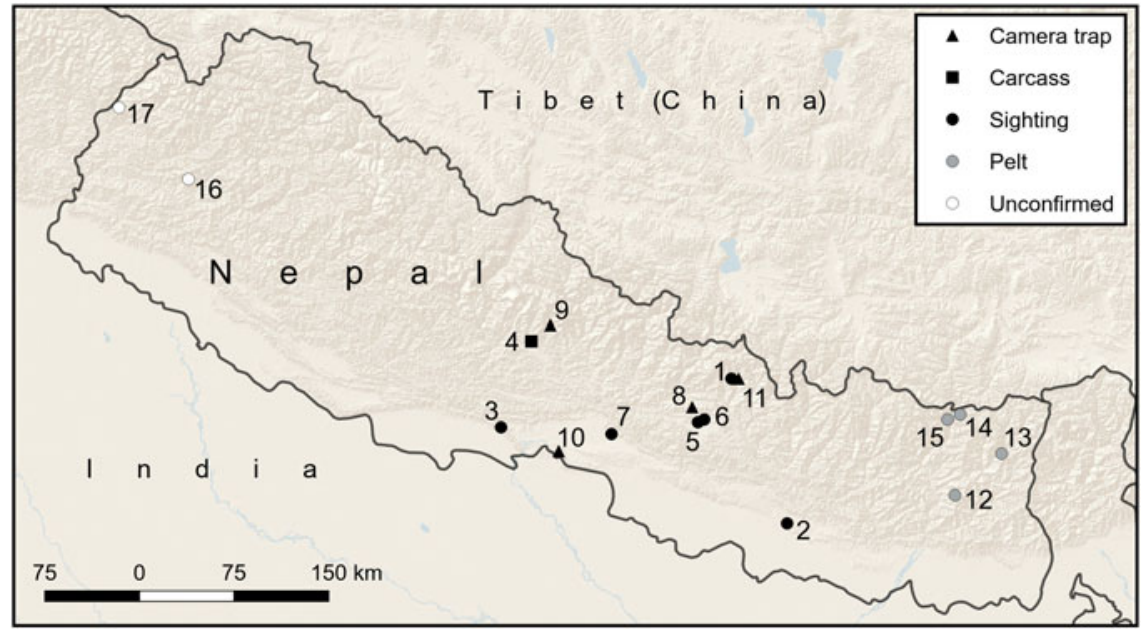

FIG. 1 Records (Numbers refer to Table 1) of the clouded leopard Neofelis nebulosa in Nepal. leopards have also been reported from marginal scrub forest in the Eastern Terai, subtropical broad-leaved forest in central Nepal and tropical broad-leaved forest in the lowlands (Dinerstein \& Mehta, 1989; Ghimirey et al., 2013; Lamichhane et al., 2014). Prey availability has been reported as a major factor influencing the occurrence of clouded leopards (Rabinowitz et al., 1987; Mohamad et al., 2015). The species has been shown to use a wider range of habitats than previously thought (Mohamad et al., 2015), and has been recorded in forests close to highly populated areas such as Kathmandu, Chitwan and Pokhara. Although the species appears to tolerate some degree of disturbance, it is important that wellconnected habitat patches remain for use and dispersal. Little is yet known of the species' ecology in lower quality habitats.

Illegal trade in the clouded leopard is prevalent in Nepal, but there are fewer cases than in South-east Asian countries (Nowell, 2007), although the number of cases has increased since 2006 (Table 1). Official data on wildlife trade can be misleading (Niraj, 2009); for example, many cases of illegal wildlife trade in Nepal go unrecorded because of the porous international border with India (Das, 2008). Even the comparatively more regulated border with China has army stations at only a few locations because of the harsh geographical conditions. Although retaliatory killings have been reported to be one of the primary threats to the clouded leopard (Jnawali et al., 2011), we found only one case of retaliatory killing of the species. We therefore suggest that retaliatory killing is probably not the most important threat to the species, as it is to the leopard Panthera pardus in Nepal.

The clouded leopard is perceived to be rare in Nepal, where it is considered to be threatened by habitat loss and degradation, and illegal wildlife trade. However, camera trapping results indicate that its frequency of occurrence and range may be increasing (Sanderson et al., 2008; Ghimirey et al., 2013). The species has also been confirmed in areas where its presence was previously unknown, including Annapurna Conservation Area, Chitwan National Park and Shivapuri Nagarjuna National Park (Pandey, 2012; Ghimirey et al., 2014; Lamichhane et al., 2014). These findings, in particular the recent camera-trap records, indicate that further research is required to clarify the distribution and status of the clouded leopard in Nepal, and that there is potential for research on the metapopulation dynamics of the species and its interactions with other felid species.

\section{Acknowledgements}

We thank Panthera, Point Defiance Zoo \& Aquarium, Point Defiance Zoo Society, and the Clouded Leopard Project for funding our field research, the Department of National Parks and Wildlife Conservation and the National Trust for Nature Conservation/Annapurna Conservation Area Project for helping with permits during our visits to various protected areas, Karan Bahadur Shah, Roshan Chaudhary, Andrew Kitchener, Anil Prajapati, Prabhat Pal, Sarita Jnawali, Ganesh Koirala, Badri Vinod Dahal, David Macdonald and Sabita Malla for providing information about clouded leopard records, Igor Khorozyan, Will Duckworth, Andreas Wilting, Christos Astaras and Nabin Baral for comments, and Kashmira Kakoti, Yam Bahadur Gurung, Ram Lama and Prem Raj Neupane for their support at various stages.

\section{Author contributions}

YG and RA both contributed to collecting the data and writing the article.

\section{References}

Austin, S.C., Tewes, M.E., Grassman, L.I. \& Silvy, N.J. (2007) Ecology and conservation of the leopard cat Prionailurus bengalensis and clouded leopard Neofelis nebulosa in Khao Yai National Park, Thailand. Acta Zoologica Sinica, 53, 1-14. 
B ARnes, L.J. (1989) The Overt Illegal Fur Trade In Kathmandu, Nepal. Report by Inverness Research Associates, Inverness, USA.

Borradaile, L., Green, M., Moon, L., Robinson, P. \& Tait, A. (1977) Langtang National Park Management Plan. HMG/UNDP/ FAO, Rome, Italy.

Brodie, J. \& Giordano, A.J. (2012) Density of the Vulnerable Sunda clouded leopard Neofelis diardi in a protected area in Sabah, Malaysian Borneo. Oryx, 46, 427-430.

DAs, P. (2008) Towards a regulated Indo-Nepal border. Strategic Analysis, 32, 879-900.

Davies, G. \& PAYne, J. (1982) A Faunal Survey of Sabah. Unpublished report by WWF Malaysia for the Game Branch, Forest Department, Sabah, Malaysia.

Dinerstein, E. \& Mehta, J.N. (1989) The clouded leopard in Nepal. Oryx, 23, 199-201.

DNPWC (Department of National Parks and Wildlife Conservation) (2012) Api-Nampa Conservation Area Leaflet. Department of National Parks and Wildlife Conservation, Kathmandu, Nepal.

Ghimirey, Y., Acharya, R., Adhikary, B., Werhahn, G. \& Appel, A. (2013) Clouded leopard camera trapped in Annapurna Conservation Area, Nepal. CAT News, 58, 25.

Ghimirey, Y., Acharya, R. \& Dahal, S. (2014) An undocumented record of a clouded leopard captured in Chitwan district, Nepal. CAT News, 60, 27-28.

Ghimirey, Y., Ghimire, B., Pal, P., Koirala, V., Acharya, R., Dahal, B.V. \& Appel, A. (2012) Status of felids in Makalu-Barun National Park, Nepal. CAT News, 56, 23-27.

Grassman, L., Lynam, A., Mohamad, S., Duckworth, J.W., Bora, J., W ILCox, D. et al. (2016) Neofelis nebulosa. The IUCN Red List of Threatened Species 2016: e.T14519A9721509o [accessed 30 June 2016].

Grassman, Jr, L.I., Tewes, M.E., Silvy, N.J. \& Kreetiyutanont, K. (2005) Ecology of three sympatric felids in a mixed evergreen forest in north-central Thailand. Journal of Mammology, 86, 29-38.

Hodgson, B.H. (1853) Felis macrosceloides. In Proceedings of the Zoological Society of London: Plate XXXVIII.

Jnawali, S.R., Baral, H.S., Lee, S., Acharya, K.P., Upadhyay, G.P., Pandey, M. et al. (compilers) (2011) The Status of Nepal's Mammals: The National Red List Series. Department of National Parks and Wildlife Conservation, Kathmandu, Nepal.

Kitchener, A.C., Beaumont, M.A. \& Richardson, D. (2006) Geographical variation in the clouded leopard, Neofelis nebulosa, reveals two species. Current Biology, 16, 2377-2383.

Lamichhane, B.R., Dhakal, M., Subedi, N. \& Pokheral, C.P. (2014) Clouded leopard co-exist with other five felids in Chitwan National Park, Nepal. Cat News, 61, 30-32.

Mohamad, S.W., Rayan, D.M., Christopher, W.C.T., Hamirul, M., Mohamad, A., Lau, C.F. \& Siwan, E.S. (2015) The first description of population density and habitat use of the mainland clouded leopard Neofelis nebulosa within a logged-primary forest in South East Asia. Population Ecology, 57, 495-503.
Niraj, S.K. (2009) Sustainable development, poaching, and illegal wildlife trade in India. PhD thesis. The University of Arizona, Tucson, USA.

Nowell, K. (2007) Asian Big Cat Conservation and Trade Control in Selected Range States: Evaluating Implementation and Effectiveness of CITES Recommendations. TRAFFIC International, Cambridge, UK.

Nowell, K. \& Jackson, P. (1996) Wild Cats: Status, Survey and Conservation Action Plan. IUCN/SSC, Gland, Switzerland.

Onlinekhabar Reporter (2015) Wildlife poacher caught with clouded leoaprd pelt and teeth. Http://www.onlinekhabar.com/2015/ 01/226212/ [accessed 7 January 2015]. [In Nepali].

Pandey, B. (2012) Clouded leopard in Shivapuri-Nagarjuna National Park, Nepal. Cat News, 57, 24-25.

Rabinowitz, A., Andau, P. \& Chai, P.P.K. (1987) The clouded leopard in Malaysian Borneo. Oryx, 21, 107-111.

Rabinowitz, A. \& Walker, S.R. (1991) The carnivore community in a dry tropical forest mosaic in Huai Kha Khaeng Wildlife Sanctuary, Thailand. Journal of Tropical Ecology, 7, 37-47.

Sanderson, J., Khan, J.A., Grassman, L. \& Mallon, D.P. (2008) Neofelis nebulosa. The IUCN Red List of Threatened Species v. 2011.2. Http://www.iucnredlist.org [accessed 14 April 2012].

SAWEN (2011) The SAWEN Bulletin, Volume 1. Department of National Parks and Wildlife Conservation, Kathmandu, Nepal.

Sнаку , M.M. (2004) Trading for Extinction: An Expose of Illegal Wildlife Trade in Nepal. WordScape, Kathmandu, Nepal.

Shakya, M.M., Pringle, C. \& Murgatroyd, C. (1999) CiteS Compliance in Nepal. Report submitted to the British Embassy, Kathmandu, Nepal.

Shrestha, M.B. (2012) Wildlife Crime Scenario: A Case Study of Kathmandu Valley. Unpublished report. Wildlife Conservation Nepal, Kathmandu, Nepal.

U PrETI, B.N. (1999) An overview of the stratigraphy and tectonics of the Nepal Himalaya. Journal of Asian Earth Sciences, 17, 577-606.

van Gruisen, J. \& Sinclair, T. (1992) Fur Trade in Kathmandu: Implications for India. TRAFFIC India, New Delhi, India.

WCN (Wildlife Conservation Nepal) (2008) Wildlife trade on the rise. Wildlife Conservation Nepal Newsletter, 5, 8.

WCN(Wildlife Conservation Nepal) (2012) Two arrested along with one leopard skin and one clouded leopard skin. Http://www. wcn.org.np/news/detailNews.php?id=26o\&title=Two arrested along with one leopard skin and one clouded leopard skin [accessed 14 August 2014].

\section{Biographical sketches}

Yadav Ghimirey has been involved in research and conservation of small felids in Nepal since 2008. He is interested in interspecific interaction among felids, particularly between clouded leopards and leopards. RA JU ACH A RY A has been involved in wildlife conservation for over 2 decades. His interests include ethno-zoology of big cats, wolves and owls. 